\title{
Genetic diversity in the Helicobacter pylori cag pathogenicity island and effect on expression of anti-CagA serum antibody in UK patients with dyspepsia
}

\author{
T M Peters, R J Owen, E Slater, R Varea, E L Teare, S Saverymuttu
}

Public Health

Laboratory,

Chelmsford CM2 0YX,

UK

T M Peters

E L Teare

Helicobacter

Reference Unit, Laboratory of Enteric

Pathogens, Central

Public Health

Laboratory, 61

Colindale Avenue,

London NW9 5HT, UK

R J Owen

E Slater

R Varea

Department of

Gastroenterology,

Broomfield Hospital,

Chelmsford CM1 7ET,

UK

S Saverymuttu

Correspondence to: $\mathrm{Dr}$

Owen

rowen@phls.nhs.uk

Accepted for publication 30 August 2000

\begin{abstract}
Aims-To investigate variation within the cag pathogenicity island (PAI) of Helicobacter pylori isolated from patients with dyspepsia in mid-Essex, and to evaluate the effect on expression of anti-CagA antibody. Methods-Sixty two isolates of $H$ pylori cultured from gastric biopsies were screened by specific PCR assays for the presence of cagA and other gene markers (cagD and cagE, and virD4) in the cag PAI. An enzyme linked immunosorbent assay (ELISA) kit (Viva Diagnostica helicobacter p120) was used to test for anti-CagA IgG antibody in matching sera. Isolates were also genotyped by vacuolating cytotoxin polymerase chain reaction (PCR) analysis, and tested for absence of the complete cag PAI (empty site PCR assay).

Results-Forty one of the $H$ pylori isolates had a cag PAI containing cagA. One strain had no cagA but other cag PAI loci were present, whereas the remaining 20 strains had no detectable cag PAI markers. Anti-CagA IgG antibody was detected in 34 sera by the ELISA assay, and when compared with the cag PAI genotype of the infecting strain, accuracy, sensitivity, and specificity were $92 \%, 87 \%$, and $100 \%$, respectively. The seven discrepant or borderline strains in the ELISA were all vacA s1 but differed in other genotypic markers. Conclusions-The cag PAI was widely distributed in $H$ pylori from patients with dyspepsia in mid-Essex who had different gastric pathologies. Infection with a strain having an uninterrupted cag PAI was associated with the presence of anti-CagA antibody in most patients. Discrepant ELISA results, mostly for elderly patients with duodenal ulcers, were attributed to cagA associated variation, particularly to the presence of mixed cagA+/cagA- cell variants in the infecting strain population. Tests for anti-CagA serum antibody were unreliable for predicting severity of clinical disease associated with $\boldsymbol{H}$ pylori infection in this series of patients.

(f Clin Pathol 2001;54:219-223)
\end{abstract}

Keywords: Helicobacter pylori; cagA; cag pathogenicity island; CagA antibody assay

Seroepidemiological surveys show that Helicobacter pylori has a worldwide distribution, and that up to $40 \%$ of the UK population is infected. ${ }^{1}$ About $80 \%$ of $\mathrm{H}$ pylori infections do not result in clinically relevant disease, even though such infections are often persistent and can be lifelong in many individuals. ${ }^{2}$ It has been proposed that certain strains of $H$ pylori may be more virulent, and a variety of strain characteristics associated with disease severity have been identified. ${ }^{34}$ One key marker is CagA, a high (120-140 kDa) molecular weight immunodominant protein encoded by the cagA gene, which is part of the cag pathogenicity island (PAI). ${ }^{5}$ The cagA gene is an important marker for the cag PAI and there is evidence that cagA is present in at least $70 \%$ of $\mathrm{H}$ pylori organisms infecting the European population ${ }^{6}$; its presence is closely correlated with the production of CagA protein, a serological marker of potentially virulent strains. ${ }^{8}$ The presence of $H$ pylori anti-CagA antibodies is widely associated with increased risk for the development of peptic ulcer disease, ${ }^{8-12}$ atrophic gastritis, ${ }^{13}{ }^{14}$ and gastric cancer. ${ }^{15-18}$ Nevertheless, the reliability, accuracy, and clinical usefulness of CagA serological and cagA genetic tests for predicting the risk of chronic gastritis, gastric cancer, and peptic ulcer disease remains controversial. ${ }^{19-22}$ The clinical interpretation of such tests is further confused by the apparent protective role of cagA positive $H$ pylori in oesophageal and gastric cardia adenocarcinoma. ${ }^{23}$

The aim of our study was to investigate the effect that diversity within the $H$ pylori cag PAI might have on CagA production, and the consequent reliability of the enzyme linked immunosorbent assay (ELISA) for the detection of host serum anti-CagA IgG antibody, and hence for use as a predictive marker for more severe $H$ pylori related disease. We examined strains of $H$ pylori isolated from gastric biopsies of 62 patients with dyspepsia to determine the frequency of cagA and other key genes in the cag PAI, and tested for anti-CagA antibody expression in matching sera.

\section{Materials and methods}

BACTERIAL STRAINS AND GROWTH CONDITIONS The 62 isolates of $H$ pylori, for which matching patient sera were available, were obtained between 1996 and 1998 from gastric biopsies of patients (39 men, age range $29.8-75$ years; and 23 women, age range $27.5-77.8$ years; mean 52.3 years) in mid-Essex undergoing routine endoscopy for a range of gastroduodenal symptoms. Patients were excluded from the 
Table 1 Primers used to amplify and identify markers in the cag pathogenicity island of Helicobacter pylori

\begin{tabular}{|c|c|c|c|}
\hline $\begin{array}{l}\text { Region } \\
\text { amplified }\end{array}$ & $\begin{array}{l}\text { Primer } \\
\text { designation }\end{array}$ & Primer sequence $\left(5^{\prime} \rightarrow 3^{\prime}\right)$ & $\begin{array}{l}\text { Amplicon } \\
\text { size }\end{array}$ \\
\hline \multirow[t]{2}{*}{$\operatorname{cagA}$} & F1 & GATAACAGGCAAGCTTTTGAGG & $349 \mathrm{bp}$ \\
\hline & B1 & CTGCAAAAGATTGTTTGGCAGA & \\
\hline \multirow[t]{2}{*}{$\operatorname{cag} \mathrm{A}$} & D008 & TAATGCTAAATTAGACAACTTGAGCGA & $298 \mathrm{bp}$ \\
\hline & R008 & TAGAATAATCAACAAACATCACGCCAT & \\
\hline \multirow[t]{2}{*}{$\operatorname{cagD} / \mathrm{E}$} & picf & GAGCTTTTGCTTGTCTTTGC & $2091 \mathrm{bp}$ \\
\hline & picr & CAAACAACGCTGCTTTCTAT & \\
\hline \multirow[t]{2}{*}{$\operatorname{virD} 4$} & $524 \mathrm{f}$ & TTCACCTCTAGTTTTAGCGG & 1993 bp \\
\hline & $524 \mathrm{r}$ & AACCTTTGGCTTTTGGTTGC & \\
\hline \multirow[t]{2}{*}{$\mathrm{ES}$} & ESf & ACATTTTGGCTAAATAAACGCTG & $360 \mathrm{bp}$ \\
\hline & $\mathrm{ESr}$ & TCATGCGAGCGGCGATGTG & \\
\hline
\end{tabular}

ES, empty site; $f$, forward primer; $r$, reverse primer.

study if they had previously received acid suppression treatment, $H$ pylori eradication treatment, or were current users of non-steroidal anti-inflammatory drugs. Patient groups based on endoscopic diagnosis before treatment were broadly defined as follows: the peptic ulcer group (13 patients); and the non-ulcer dyspeptic group with diagnoses of gastritis and/or duodenitis (16 patients), oesophagitis (19 patients), gastric neoplasia (two patients), and endoscopically normal mucosa including normal oesophagus, stomach, and duodenum (nine patients).

The biopsy specimens were homogenised in Griffith's tubes, inoculated on to $10 \%$ (vol/vol) Columbia blood and selective (DENT) agars (Oxoid, Basingstoke, UK) and incubated at $37^{\circ} \mathrm{C}$ under microaerophilic conditions (5\% $\mathrm{O}_{2}, 5 \% \mathrm{CO}_{2}, 2 \% \mathrm{H}_{2}, 88 \% \mathrm{~N}_{2}$ ) for five days. After primary isolation, all isolates of $\mathrm{H}$ pylori were cultured for two to three days on $10 \%$ (vol/vol) Columbia blood agar (Oxoid) at $37^{\circ} \mathrm{C}$ as above. Stock cultures were preserved on glass beads in nutrient broth (Oxoid) containing $10 \%$ (vol $/ \mathrm{vol})$ glycerol over liquid nitrogen or at $-80^{\circ} \mathrm{C}$.

Reference cultures of $H$ pylori (in lyophilised form) as controls for the various polymerase chain reaction (PCR) assays were obtained from the National Collection of Type Cultures (NCTC, London), namely: NCTC 11637 (the type strain, cagA+), NCTC 12455 (strain 26695, cagA+), ${ }^{24}$ NCTC 12908 (G50, cagA-), ${ }^{5}$ and NCTC 13081 (strain Tx30a, cagA-)..$^{5}$

ELISA FOR DETECTION OF SERUM IgG ANTIBODIES TO CAGA PROTEIN

Serum samples were obtained from blood, taken at the time of endoscopy, from the 62 patients and were stored at $-80^{\circ} \mathrm{C}$ until serological testing was performed. An ELISA using a highly purified p120 antigen of $H$ pylori (Viva Diagnostica Helicobacter p120 ELISA; supplied by Axis-Shield, Dundee, UK) was performed according to the manufacturer's instructions to detect anti-CagA serum IgG. The cut off values for the ELISA as recommended by the manufacturer were $:<5$ units, negative; 5-7.5 units, borderline; $>7.5$ units, positive. Control sera provided with the kit were used for semiquantitative analysis.
EXTRACTION, PRIMERS FOR CAG PAI LOCI, AND PCR CONDITIONS

Genomic DNA was extracted from strains of $H$ pylori grown on $10 \%$ Columbian blood agar and purified by means of the Isoquick kit (Orca Research, Bothell, Washington, USA) or the cetylrimethyammonium bromide (CTAB) method. ${ }^{25}$ Diluted DNA (100 ng) was added to each PCR reaction containing: $10 \mathrm{mM}$ Tris/ $\mathrm{HCl}$ (pH 8.3), $50 \mathrm{mM} \mathrm{KCl}, 1.5 \mathrm{mM} \mathrm{MgCl}$, $0.05 \mathrm{mM}$ each deoxynucleotide, and $0.4 \mathrm{mM}$ each oligonucleotide primer, which were synthesised by MWG-BIOTECH (Milton Keynes, UK). One unit Taq polymerase (Life Technologies, Paisley, UK) was added and PCR was performed in a Sprint thermal cycler (Hybaid Ltd, Ashford, UK).

Details of the primers and PCR conditions for the various assays have been described elsewhere. ${ }^{26}$ Briefly, these were as follows. PCR conditions for the two assays for cagA (a marker for the right hand end of the cag PAI and for the cagI region) were as described previously for the F1/B1 primers ${ }^{27}$ and the D008/ F008 primers. $^{28}$ The assay for cagD and cagE (also referred to as part of the picAB operon, where picA comprises cagC and cagD, and picB is cagE), ${ }^{29}$ which is located within the cagI region upstream of $\mathrm{cagA},{ }^{30}$ was used as a second marker for that region. The primers were designed to amplify both cagD and cagE to give a $2091 \mathrm{bp}$ product based on the published sequences for NCTC 12455 (table 1). ${ }^{24}$ The PCR amplification comprised one cycle of $94^{\circ} \mathrm{C}$ for 110 seconds followed by 25 cycles of $94^{\circ} \mathrm{C}$ for 50 seconds, $54^{\circ} \mathrm{C}$ for $50 \mathrm{sec}-$ onds, $72^{\circ} \mathrm{C}$ for 110 seconds, and finally $72^{\circ} \mathrm{C}$ for three minutes. The gene locus identified as a virD4 homologue ( $\mathrm{Hp} \mathrm{524)}$ was selected as a marker for the cagII region, ${ }^{29}$ and two primers were designed to give a $1993 \mathrm{bp}$ product based on the NCTC 12455 sequence $^{24}$ (table 1). The PCR amplification conditions used comprised one cycle at $94^{\circ} \mathrm{C}$ for two minutes followed by 30 cycles at $94^{\circ} \mathrm{C}$ for one minute, $56^{\circ} \mathrm{C}$ for one minute, and finally $72^{\circ} \mathrm{C}$ for two minutes. The empty site (ES) assay ${ }^{31}$ was used to test for absence of the complete cag PAI. A $360 \mathrm{bp}$ fragment was amplified with primers 2 and 25 specific for the genome regions flanking the left and right ends of the cag PAI insert location for NCTC 12455 (table 1). The PCR amplification conditions used were 35 cycles at $94^{\circ} \mathrm{C}$ for one minute, $57^{\circ} \mathrm{C}$ for one minute, and $72^{\circ} \mathrm{C}$ for one minute.

VACUOLATING CYTOTOXIN GENOTYPING

The strains of $H$ pylori that were negative or borderline in the CagA ELISA were genotyped based on the signal (s1 and $\mathrm{s} 2$ ) and mid ( $\mathrm{m} 1$ and $\mathrm{m} 2$ ) regions of the vacuolating cytotoxin gene (vacA). Genotyping was performed using previously described PCR conditions and the following primers: VA1-F and VA1-R for the $\mathrm{s}$ region, ${ }^{32}$ giving fragments of $259 \mathrm{bp}$ for $\mathrm{s} 1$ and $289 \mathrm{bp}$ for s2; and VAG-F and VAG-R for the $\mathrm{m}$ region, giving fragments of $570 \mathrm{bp}$ for $\mathrm{m} 1$ and $645 \mathrm{bp}$ for $\mathrm{m} 2 .^{33}$ 
Table 2 Serology results with the CagA ELISA for serum from Helicobacter pylori infected individuals

\begin{tabular}{llll}
\hline \multirow{2}{*}{$\begin{array}{l}\text { H pylori cag PAI genotype: status of } \\
\text { infecting strain }\end{array}$} & \multicolumn{2}{l}{ Number of sera giving the following CagA ELISA result } \\
\cline { 2 - 4 } & Positive & Negative & Borderline \\
\hline cagA+ (cagDE/virD4 not tested) & 34 & 5 & 2 \\
cagA-/cagDE+(virD4 not tested) & 0 & 0 & 0 \\
cagA-/cagDE-/virD4+ & 0 & 1 & 0 \\
cagA-/cagDE-/virD4- & 0 & 20 & 0 \\
Total & 34 & 26 & 2 \\
\hline
\end{tabular}

ELISA, enzyme linked immunosorbent assay; PAI, pathogenicity island.

\section{Results}

CAG PAI GENOTYPES

The 62 isolates of $H$ pylori, each from a different patient, were tested for the presence of the cag PAI using the panel of PCR assays, and the results are shown in table 2 . A hierarchical scheme of assays was used to minimise the number of individual PCR tests, because it was established previously that a positive cagA result was a reliable predictor of positivity for cagD and cagE (picAB). ${ }^{26}$ Overall, 34 strains were shown to have cagA with one or both of the two cagA assays. Seventeen of those strains were negative with the F1/B1 primers but were positive with the D008/F008 primers. Strains of $H$ pylori that were confirmed negative for cagA in the above assays were tested also for the presence of cagD and cagE, which are key components of the cagI region of the cag PAI. No strains with the cagA-/cagDE+ genotype were identified.

Strains of $H$ pylori that were negative in the above PCR assays were then tested using the virD4 assay, which provided a marker of the cagII region. One positive strain appeared to have a diverged cag PAI, in which the two markers (cagA and cagDE) for the cagI region had been deleted, although the cagII region indicated by virD 4 was conserved. Because the remaining 20 strains of $H$ pylori were negative in the above PCR assays, it may be that they have neither a complete nor a partial cag PAI. However, owing to the large size (about $40 \mathrm{~kb}$ ) of the cag PAI, the absence of these specific markers did not necessarily indicate its complete absence. Such cagA-/cagDE-/virD4strains were the second most common group and a feature of 20 of 62 of all strains in our series of patients. The distribution of the $H p y$ lori cagA+ and cagA- strains according to the patient disease categories were as follows: 12 strains, peptic ulcer group; 19 strains, oesophagitis group; 16 strains, gastritis group, 14 strains endoscopically normal mucosa; and one strain, gastric cancer. The relative numbers of strains with the cagA positive genotype were similar in each disease group.

DETECTION OF ANTI-CAGA ANTIBODY AND ASSOCIATIONS WITH CAG PAI GENOTYPE

The 62 human sera that matched the strains of $H$ pylori isolated from gastric biopsies before treatment were investigated. When tested for the presence of anti-CagA antibody by ELISA, a total of 34 patients showed CagA positivity, with two additional sera giving borderline results. Twenty one sera gave a negative ELISA

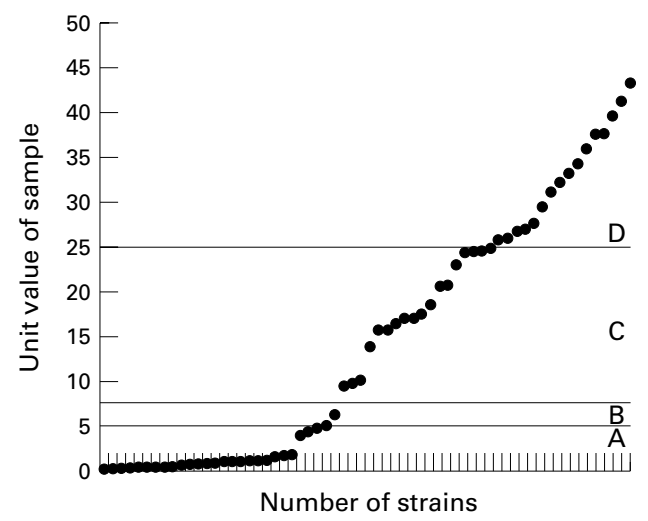

Figure 1 The range of semiquantitative values for Helicobacter pylori CagA enzyme linked immunosorbent assay. Each point represents one strain. $A$, negative zone; $B$, borderline zone; $C$, positive zone; and $D$, strong positive zone.

Table 3 Evaluation of ELISA for detecting anti-CagA antibody in sera of Helicobacter pylori infected patients

\begin{tabular}{llll}
\hline & \multicolumn{2}{l}{ Genotype } & \\
\cline { 2 - 3 } & cagA+ & cagA- & Total \\
\hline ELISA test + & 36 & 0 & 36 \\
ELISA test - & 5 & 21 & 26 \\
Total & 41 & 21 & 62
\end{tabular}

Borderline results are included as positive results.

Sensitivity is $36 / 41$, or $87.8 \%$; specificity is $21 / 21$, or $100 \%$; predictive value of a positive test is $36 / 36$, or $100 \%$; predictive value of a negative test is $21 / 26$, or $80.8 \%$; accuracy is $36+21 / 62$, or $91.9 \%$.

ELISA, enzyme linked immunosorbent assay.

result. Figure 1 shows the distribution of semiquantitive values obtained in the ELISA assay.

Table 2 lists the serology results with the corresponding cag PAI genotype of the infecting $H$ pylori strain. For the 41 cagA+ strains, anti-CagA antibodies were detected in 34 matching sera. However, sera from five patients were negative for CagA even though the cagA gene was present in the PAI of the infecting strain. Overall, 20 strains lacked all genetic markers for the cag PAI, and all the corresponding sera were negative for anti-CagA antibody. One further strain had a partial cag PAI but had no cagA according to the PCR assays, and the patient was CagA seronegative.

Analysis of the CagA ELISA results (table 3), with borderline results included as positives, shows that sensitivity, specificity, positive predictive value, negative predictive value, and accuracy were $87.8 \%, 100 \%, 100 \%, 80.8 \%$, and $91.9 \%$, respectively, when compared with the results for presence of the cagA gene in the infecting strain (used as the "true" test result).

ATYPICAL ELISA RESULTS AND GENOTYPES OF THE INFECTING H PYLORI STRAINS

Atypical results were obtained for seven sera and paired cultures of $H$ pylori. Sera from five patients gave a negative CagA ELISA result although the infecting strain of $H$ pylor $i$ in each case was cagA positive (table 4). These five strains were cagA positive with the D008/D009 primers but were cagA negative with the F1/B1 primers. Two other atypical strains (H6 associated with duodenal ulcer, and H339 from a 68 year old patient with gastric neoplasia) were 
Table 4 Features of Helicobacter pylori isolates and patients with sera giving negative or borderline results in the CagA ELISA assay

\begin{tabular}{|c|c|c|c|}
\hline Strain & Strain genotype & $\begin{array}{l}\text { Patient age } \\
\text { (years) }\end{array}$ & Clinical details \\
\hline \multicolumn{4}{|c|}{ CagA- ELISA } \\
\hline $\mathrm{H} 292$ & $\mathrm{cag}^{\star} / \mathrm{s} 1 \mathrm{~m} 1 / \mathrm{ES}+\star$ & 35 & DU \\
\hline H293 & $\mathrm{cagA}^{\star} / \mathrm{s} 1 \mathrm{~m} 2 / \mathrm{ES}+$ & 55 & Mild oesophagitis \\
\hline H115 & $\mathrm{cagA}^{\star} / \mathrm{s} 1 \mathrm{~m} 2 / \mathrm{ES}-\star$ & 56 & GU \\
\hline $\mathrm{H} 377$ & $\mathrm{cagA}^{\star} / \mathrm{s} 1 \mathrm{~m} 2 / \mathrm{ES}-\star$ & 75 & GU/DU \\
\hline H298 & cagA/s1m2/ES-^ & 67 & DU \\
\hline \multicolumn{4}{|c|}{ Borderline CagA ELISA } \\
\hline H6 & $\operatorname{cag} \mathrm{A} / \mathrm{s} 1 \mathrm{~m} 2 / \mathrm{ES}-\star \star$ & 37 & DU \\
\hline H339 & $\mathrm{cagA}^{\star} / \mathrm{s} 1 \mathrm{~m} 1 / \mathrm{ES}-\star$ & 68 & Gastric neoplasia \\
\hline
\end{tabular}

Strain genotype: cagA ${ }^{\star}$, strain gave negative result with $\mathrm{F} 1 / \mathrm{B} 1$ primer pair but was positive with the F008/R008 primer pair; ES $+^{\star}$, non-specific product amplified as well as predicted amplicon; ES-^, only non-specific product amplified.

DU, duodenal ulcer; ELISA, enzyme linked immunosorbent assay; GU, gastric ulcer.

also cagA + but were borderline in the CagA ELISA assay. Additional genotyping (vacA sm and ES assay) of these seven strains showed that they were genomically diverse. The ES assay results were unusual because two strains gave a positive ES amplicon even though they contained cagA, and the other five strains gave a non-specific product in the ES assay. These atypical CagA ELISA results were most often associated with cultures and sera from patients aged over 55 with more severe disease such as duodenal ulcer (five patients) or gastric neoplasia (one patient).

\section{Discussion}

Serological detection of infection with a cagA containing strain of $H$ pylori by means of an anti-CagA ELISA is the only non-invasive diagnostic test at present available for assessing strain virulence potential and possible disease risk. It is important, therefore, to establish the reliability of CagA serology as a predictive test for determining the cagA genotype of the infecting strain because various serological assays are now available. ${ }^{21}$ Our study was designed to determine the link between the composition of the strain cag PAI and the host response to exported CagA protein, as measured by anti-CagA IgG serum production. One possible problem in assessing such a serological test is the reliability of the cagA PCR assay because the correct design of primers is crucially important as a result of strain genomic diversity. Our results indicated that the $\mathrm{F} 1 / \mathrm{B} 1$ primer pair resulted in a $50 \%$ underestimation of the number of strains containing cagA. In a previous study of $H$ pylori from Italian patients, the problem of different sets of cagA primers giving different results was highlighted and attributed to divergence in the primer target sequences. ${ }^{34}$ It is important, therefore, to investigate other genes within the cag PAI to establish alternative markers of the degree of conservation.

For most of the 62 patients in our study, we found a direct correlation between the presence of the cagA gene in the infecting strain of $H$ pylori and anti-CagA antibody seropositivity of the host, giving an accuracy of $91.9 \%$ for the CagA ELISA assay. The sensitivity of the assay was $87.8 \%$ because five patients were serologically CagA negative, even though the cagA gene and the rest of the cag PAI were conserved in the genomes of each of the infecting strains.
These apparently "false negative" results in the ELISA assay have several possible explanations. First, the cagA gene could have been functional but mutations might have arisen in other loci within the cag PAI that modified the ability of the cell to export active CagA protein, so causing a lack of seropositivity. However, this is unlikely because most investigations show a close correlation between the presence of the cagA gene and expressed CagA protein. ${ }^{85}$ Second, sequencing of the cagA gene in $H$ pylori shows a region of internal duplication present in some strains, which may be responsible for the heterogeneity seen in CagA size. ${ }^{8}$ This variation has been reported to be located in the $3^{\prime}$ region, with differences in the number and size of repeats. ${ }^{21}$ Our negative PCR results for the $F 1 / B 1$ primers indicated variation within cagA of four of these "atypical" strains, and also for another strain (H339), which gave a borderline CagA ELISA result. Thus, genetic variation within cagA might generate antigenic diversity different from and not reflected in the CagA antigen coating the ELISA plate well, thereby resulting in failure to detect CagA antibody. Because details of the strain(s) used as source of antigen in the kit were not available, it was not possible to assess this further.

Another possible explanation of the discrepancy between the genetic and phenotypic assays was that the cultures of the infecting $H$ pylori were a cagA+/cagA- mixture of cell types. Such mixtures of $H$ pylori have been documented previously. ${ }^{36} 37$ In addition, the results of the ES PCR assay for most of these strains indicated that cagA- variants were present as well as cagA+ forms. If the proportion of cagA+ to cagA- cell types in the infecting $H$ pylori population was low, then there might have been insufficient CagA protein exported in vivo to induce a host response, even though there was enough DNA from cagA- cells on subculture to give a positive result in the ES PCR assay. Host factors might also have contributed to the observed discrepancies because it has been suggested that host responses to $H$ pylori may vary in different populations and in different age ranges. These particular patients were mostly over 55 years of age and had a severe disease (gastric ulcer or neoplasia), which might have contributed to a diminished immunological response to the $H$ pylori infection. However, in older patients the incidence of positive antibodies initially increases with age, such that at 55 to 60 years, $50-60 \%$ of the general population will show raised antibody values, irrespective of whether they have an active infection, whereas antibody responses in the very elderly may be weak or non-existent because of a general decline in the immune system.

In summary, we found that the cag PAI was common in $H$ pylori infected patients attending an open access endoscopy clinic in mid-Essex, and there was no reliable evidence that the cag PAI containing strains were more often associated with peptic ulcers in this series of patients. In general, the results using the Viva Diagnostica Helicobacter p120 ELISA kit for detecting 
anti-CagA antibody in patient sera closely matched the infecting strain cag PAI genotype. False negative results ( $10 \%$ of sera) were best interpreted in the context of mixed infections, in particular cagA+/cagA- culture mixtures, as well as diversity within cagA, although limitations of the kit cannot be excluded because of some difficulties in interpreting borderline results. We conclude that the increasing availability of diagnostic tests, such as the CagA ELISA, provides the potential to make improvements in the management of $H$ pylori infection in primary care. However, the results of such tests should be interpreted with caution in view of the fact that some negative ELISA results may lead to incorrect assumptions about the cagA status of the infecting $\mathrm{H}$ pylori strain. The ELISA appeared to be least reliable in older patients with more severe disease. Consequently, the value of predicting the clinical outcome of an $H$ pylori infection based on cagA status alone must remain uncertain until the role of other possible determinants, such as host immunological and geographical status factors, as well as other $H$ pylori strain specific virulence factors, have been clarified.

This work was supported in part by a three year award from the PHLS Central R \& D Fund (1995-98).

1 Pounder RE, Ng D. The prevalence of Helicobacter pylori infection in different countries. Aliment Pharmacol Ther 1995;9(suppl 2):33-9.

2 Blaser MJ. Helicobacter pylori and gastric diseases. BMF 1998;316:1507-10.

3 Blaser MJ. Not all Helicobacter pylori strains are created equal: should all be eliminated? Lancet 1997;349:1020-2.

4 Dunn BE, Cohen H, Blaser MJ. Helicobacter pylori. Clin Microbiol Rev 1997;10:720-41.

5 Censini S, Lange C, Xiang Z, et al. Cag, a pathogenicity island of Helicobacter pylori, encodes type I-specific and disease-associated virulence factors. Proc Natl Acad Sci U S A 1996;93:14648-53.

6 Owen RJ, Hurtado A, Banatvala N, et al. Conservation of the cytotoxin-associated (cagA) gene of Helicobacter pylori and investigation of association with vacuolating-cytotoxin activity and gastroduodenal disease. FEMS Immunol Med Microbiol 1994;9:307-16.

7 Jenks PJ, Megraud F, Labigne A. Clinical outcome after infection with Helicobacter pylori does not appear to be reliably predicted by the presence of any of the genes of the cag pathogenicity island. Gut 1998;43:752-8.

8 Covacci A, Censini S, Bugnoli M, et al. Molecular characterisation of the $128-\mathrm{kDa}$ immunodominant antigen of Helicobacter pylori associated with cytotoxicity and of Helicobacter pylori associated with cytotoxicity and

9 Cover TL, GlupczybakiY, Lage AP, et al. Serologic detection over TL, GlupczybakiY, Lage AP, et al. Serologic detection
of infection with cagA + Helicobacter pylori strains. $\mathcal{F}$ Clin of infection with cagA+ Helico

10 Crabtree JE, Taylor JD, Wyatt JI, et al. Mucosal IgA recognition of Helicobacter pylori $120 \mathrm{kDa}$ protein, peptic ulceration and gastric pathology. Lancet 1991;338:332-5.

11 Weel JFL, van der Hulst RWM, Gerrits Y, et al. The interrelationship between cytotoxin-associated gene A, vacuolating cytotoxin, and Helicobacter pylori-related diseases. $\mathcal{F}$ Infect Dis 1996;173:1171-5.

12 Ching CK, Wong BCY, Kwok E, et al. Prevalence of CagAbearing Helicobacter pylori strains detected by the anti-CagA assay in patients with peptic ulcer disease and in controls. Am f Gastroenterol 1996;91:949-53.

13 Beales ILP, Crabtree JE, Scunes D, et al. Antibodies to CagA protein are associated with gastric atrophy in Helicobacter protein are associated with gastric atrophy in Helicobacter

14 Kuipers EJ, Perez-Perez GI, Meuwissen SGM, et al. Helicobacter pylori and atrophic gastritis: importance of the cagA status. F Natl Cancer Inst 1995;87:1777-80.
15 Blaser M, Perez-Perez GI, Kleanthous TL, et al. Infection with Helicobacter pylori strains possessing cagA is noma of the stomach. Cancer Res 1995;55:2111-15.

16 Crabtree JE, Wyatt JI, Sobala GM, et al. Systematic and mucosal humoral responses to Helicobacter pylori in gastric cancer. Gut 1993;34:1339-43.

17 Parsonnet J, Friedman GD, Orentreich N, et al. Risk for astric cancer in people with CagA positive or CagA negative Helicobacter pylori infection. Gut 1997;40:297-301.

18 Shimoyama T, Fukuda M, Tanaka T, et al. High prevalence of the CagA-positive Helicobacter pylori strains in Japanese asymptomatic patients and gastric cancer patients. Scand $\mathcal{F}$ Gastroenterol 1997;32:465-8.

19 Mitchell HM, Hazell SL, Li YY, et al. Serological response to specific Helicobacter pylori antigens: antibody against CagA antigen is not predictive of gastric cancer in a developing country. Am f Gastroentrol 1996;91:1785-8.

20 Graham DY, Genta RM, Graham DP, et al. Serum CagA antibodies in asymptomatic subjects and patients with pepic ulcer: lack of correlation of IgG antibody in patients with peptic ulcer or asymptomatic Helicobacter pylori gasritis. F Clin Pathol 1996;49:829-32.

21 Yamaoka Y, Kodama T, Graham D, et al. Comparison of four serological tests to determine the CagA or VacA status of Helicobacter pylori strains. F Clin Microbiol 1998;36: 3433-4.

22 Heikkinen $M$, Janatuinen $\mathrm{K}$, Mayo K. Usefulness on anti-Helicobacter pylori and anti-CagA antibodies in the selection of patients for gastroscopy. Am 7 Gastroenterol 1997;92:2225-9.

23 Chow WH, Blaser MJ, Blot WJ, et al. An inverse relation between cagA+ strains of Helicobacter pylori infection and risk of esophageal and gastric cardia adenocarcinoma. Cancer Res 1998;58:588-90.

24 Tomb JF, White O, Kerlavage AR, et al. The complete genome sequence of the gastric pathogen Helicobacter genome sequence of the gastric
pylori. Nature 1997;388:539-47.

25 Wilson K. Preparation of genomic DNA from bacteria. In: Ausubel FMR, Brent R, Kingston E, et al, eds. Current progress in molecular biology. New York: Wiley, 1987:unit 2.4 .1

26 Slater E, Owen RJ, Williams M, et al. Conservation of the cag pathogenicity island of Helicobacter pylori: associations with vacuolating cytotoxin allele and IS605 diversity. Gastroenterology 1999;117:1-9.

27 Tummuru MKR, Cover TL, Blaser MJ. Cloning and expression of a high molecular weight major antigen of Helicobacter pylori: evidence of linkage to cytotoxin production. Infect Immun 1993;61:1799-809.

28 Covacci A, Rappuoli R. PCR amplification of gene sequences from Helicobacter pylori strains. In: Lee A, Megraud F, eds. Helicobacter pylori: techniques for clinical diagnosis and basic research. London: WB Saunders diagnosis and basic research.

29 Covacci A, Falkow S, Berg DE, et al. Did the inheritance of a pathogenicity island modify the virulence of Helicobacter pylori? Trends Microbiol 1997;5:205-8.

30 Tummuru KR, Sharma SA, Blaser MJ. Helicobacter pylori picB, a homologue of the Bordetella pertussis toxin secretion protein, is required for induction of IL-8 in gastric epithelial cells. Mol Microbiol 1995;18:867-76.

31 Akopyants NS, Clifton SW, Kersulyte D, et al. Analysis of the cag pathogenicity island of Helicobacter pylori. Mol Microbiol 1998;28:37-53.

32 Atherton JC, Cao P, Peek RM, et al. Mosaicism in vacuolating cytotoxin alleles of Helicobacter pylori. $f$ Biol Chem 1995;30:17771-7.

33 Atherton JC, Cover TL, Twells RJ, et al. Simple and accurate PCR-based system for typing vacuolating cytotoxin alleles of Helicobacter pylori. $\mathcal{F}$ Clin Microbiol $1999 \cdot 37 \cdot 2979-82$.

34 Busolo F, Bertollo G, Bordignon G, et al. Detection and characterisation of Helicobacter pylori from patients with gastroduodenal diseases. Diagn Microbiol Infect Dis 1998; 31:531-6.

35 Xiang Z, Censini S, Bayeli PF, et al. Analysis of expression of cagA and vacA virulence factors in 43 strains of Helicobacter pylori reveals that clinical isolates can be divided into two major types and that cagA is not necessary for expression of the vacuolating cytotoxin. Infect Immun 1995;63:94-8.

36 Fantry GT, Zheng QX, Darwin PE, et al. Mixed infection with cagA positive and cagA negative strains of Helicobacter pylori. Helicobacter 1996;1:98-106.

37 Figura N, Vindigni C, Covacci A, et al. cagA positive and negative Helicobacter pylori strains are simultaneously present in the stomach of most patients with non-ulcer dyspepsia: relevance to histological damage. Gut 1998;42: $772-8$ 